\title{
Metode Analisis Struktur Perahu
}

\section{Fadjar Ibnu Thufail}

Keywords: maritime, archaeology, classification, analysis, boat, ship

\section{How to Cite:}

Thufail, F. I. (1993). Metode Analisis Struktur Perahu. Berkala Arkeologi, 13(2), 2845. https://doi.org/10.30883/jba.v13i2.575

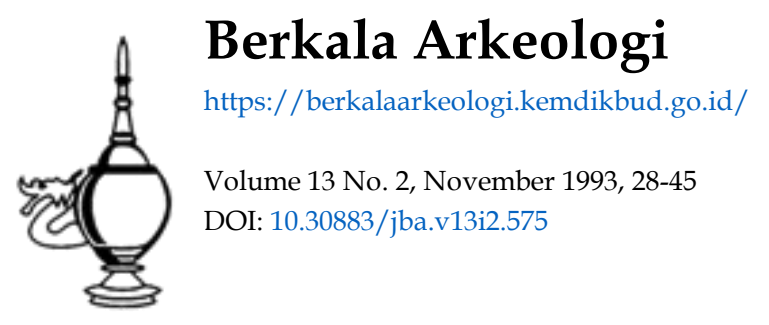




\title{
METODE ANALISIS STRUKTUR PERAHU
}

\author{
Fadjar Ibnu Thufail \\ (Puslitbang Kemasyarakatan dan Kebudayaan LIPI)
}

Di samping beraneka ragam cabang spesialisasi yang ada di dalam disiplin arkeologi, arkeologi maritim merupakan cabang yang masih kurang peminatnya. Sejauh ini, arkeologi maritim masih dipahami sebagai terjemahan langsung dari under water archaeology, suatu kegiatan penelitian arkeologis yang dilakukan di bawah air. Metodologi yang dikembangkan cenderung berorientasi kepada teknikteknik penyelamatan artefak bawah air, yang dilakukan melalui ekskavasi, restorasi, atau konservasi.

Arkeologi maritim sebenarnya dapat dipahami secara lebih luas daripada sekedar under water archaeology. Jika titik tolak kajian arkeologis adalah semua bentuk material culture, maka obyek kajian arkeologi maritim adalah semua bentuk budaya materi yang mempunyai keterkaitan erat dengan wilayah perairan, seperti misalnya berupa perahu, alat tangkap ikan, atau alat petunjuk navigasi.

Seperti juga cabang-cabang arkeologi yang lain, arkeologi maritim juga memerlukan metode klasifikasi dan analisis yang sistematis terhadap data artefaktualnya. Langkah pertama adalah membentuk sistem klasifikasi yang baik, untuk menghasilkan tipologitipologi yang dapat digunakan sebagai dasar untuk analisis selanjutnya.

Seperti telah dikemukakan di atas, obyek kajian arkeologi maritim adalah semua bentuk budaya materi yang mempunyai keterkaitan erat dengan aktivitas-aktivitas kemaritiman. Sesuai dengan sifat data arkeologi pada umumnya, maka artefak arkeologi maritim biasanya ditemukan juga dalam keadaan yang sudah tidak lengkap lagi. Oleh karena itu, untuk membentuk sebuah model yang dapat dijadikan sebagai dasar kajian tipologi maka diperlukan data-data pembantu dari studi etnografi maupun sejarah tertulis.

Perahu adalah salah satu bentuk budaya materi yang sangat berkaitan dengan kehidupan masyarakat maritim. Di beberapa wilayah Indonesia telah ditemukan situs-situs perahu kuna yang membuktikan bahwa perahu adalah salah satu moda transportasi air yang dikenal pada masa lalu. Tetapi, sampai saat ini belum pernah dilakukan kajian yang komprehensif dalam rentang sejarah terhadap perahu sebagai 
salah satu hasil budaya manusia. Hal ini disebabkan karena belum adanya satu patokan dasar dalam analisis tipologi perahu karena sebagian besar perahu kuna yang ditemukan sudah tidak utuh lagi. Salah satu cara untuk mengatasi keterbatasan ini ialah dengan memanfaatkan data-data etnografi perahu tradisional dan sumbersumber sejarah tertulis.

Perahu pada umumnya merupakan nama yang digunakan untuk salah satu jenis alat transportasi air. Di samping perahu, dikenal juga alat transportasi air lain yaitu rakit. Perahu adalah alat kendaraan di air yang biasanya tidak bergeladak (Poerwadarminta, 1982: 734). ${ }^{1}$

Untuk membuat suatu standar klasifikasi perahu, maka langkah awal yang harus dilakukan ialah mengenal struktur perahu secara rinci. Pada studi awal ini patokan dasar yang dipakai untuk dasar pembentukan model untuk klasifikasi adalah bahan dan bentuk, karena dua komponen inilah yang paling penting dalam teknik pembuatan perahu tradisional. Konsep bentuk mencakup hal-hal yang berkaitan dengan tampilan fisik dan konstruksi.

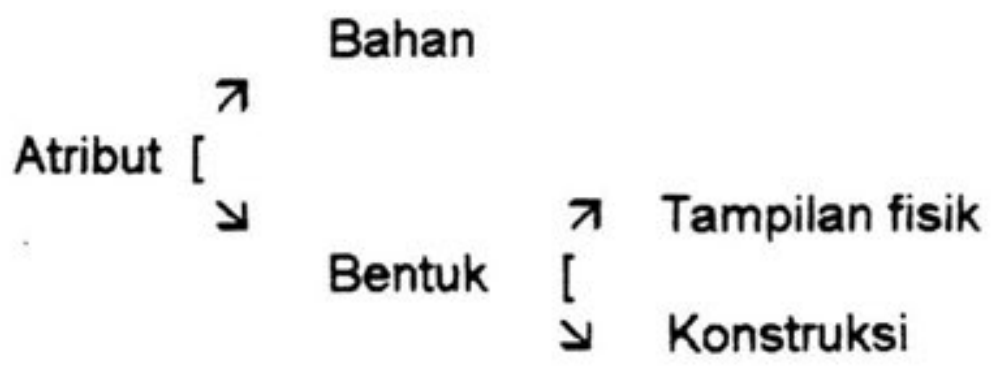

\section{A. Perkembangan Struktur Perahu}

Sampai saat ini teori tentang awal kemampuan manusia untuk melakukan perjalanan melintas laut selalu dikaitkan dengan persebaran ras manusia. Persebaran Homo erectus dari Afrika sampai ke Cina dan Jerman mungkin adalah saat awal manusia mampu melintasi laut, yaitu Selat Gibraltar (Johnstone, 1980:3).

Pendapat lain mengatakan bahwa kemampuan manusia untuk malintasi laut muncul bersamaan dengan menurunnya kemampuan manusia untuk berenang, yang disebabkan karena adanya evolusi fisik Homo sapiens. Akibat dari evolusi tersebut adalah manusia mulai dapat berjalan secara tegak, sehingga kedua lengan atas menjadi bebas. Bebasnya kedua lengan atas itu mengurangi kemampuannya untuk 
melakukan gerakan-gerakan alami yang diperlukan untuk berenang, oleh karena itu manusia mulai membutuhkan alat bantu di air (Johnstone, 1980:3).

Alat transportasi air paling awal berbentuk batang kayu terapung, yang dimanfaatkan sebagai alat transportasi sungai. Penggunaan batang kayu terapung ini dimungkinkan oleh kondisi arus sungai yang tak terlalu deras. Pengendaliannya dilakukan dengan menggunakan dayung oleh orang yang duduk mengapit batang kayu tersebut (Johnstone 1980:7).

Penggunaan batang kayu tunggal tersebut kemudian mendasari munculnya alat transportasi air yang berbentuk rakit. Tahap pertama perkembangan rakit ialah berbentuk batang-batang kayu yang diikat menjadi satu secara horizontal. Tahap kedua ditandai dengan penambahan satu lapis balok-balok kayu yang dikat dengan arah bersilang di atas lapisan balok yang pertama, sehingga rakit tersebut terdiri dari beberapa lapis balok kayu. Bentuk rakit kayu yang paling canggih adalah dengan adanya penambahan beberapa baris kayu yang disusun sedemikian rupa sehingga membentuk semacam pagar di sekeliling rakit. Bentuk semacam ini dinamakan perahu-rakit (raft-boat) (Johnstone 1980:7-8).

Pemanfaatan balok kayu tunggal sebagai alat transportasi air juga terdapat dalam bentuk perahu lesung (dug-out canoe). Perahu ini terbuat dari satu balok kayu besar dan panjang yang dilubangi di bagian tengahnya, sehingga menyisakan sisi-sisi balok kayu yang berbentuk lesung. Perahu lesung yang tertua ditemukan di Pesse, Belanda, berasal dari $6315 \mathrm{SM}$. menurut pertanggalan radiocarbon (Johnstone 1980:46).

Jenis transportasi air yang merupakan perkembangan dari perahu lesung adalah perahu papan. Evolusi perahu lesung menjadi perahu papan dimulai dari proses penambahan papan di kedua sisi perahu lesung untuk meningkatkan kemampuan apungnya dan daya muat yang lebih besar. Teknik tertua untuk penyambungan papan tersebut adalah dengan ikatan (lashing) atau "jahitan" (sewing). Pada masa yang lebih muda barulah dikenal penggunaan paku kayu (treenails) dan paku besi (iron-nails) (Johnstone 1980:50-51).

Kebutuhan akan alat transportasi air yang dapat memuat beban banyak semakin bertambah, maka lambat laun badan perahu digantikan oleh konstruksi papan. Konstruksi itu memungkinkan dibangunnya perahu yang lebih besar. 
Perahu papan yang tertua di Eropa berasal dari jaman perunggu pertengahan, dibangun dengan teknik carvel-built dan clinker-built, ${ }^{2}$ yang diperkuat dengan ikatan dan "jahitan". Penggunaan paku baru muncul pada periode Romawi (Bray and Trump 1976:39).

\section{B. Klasifikasi Struktural}

Di berbagai belahan dunia telah ditemukan banyak perahuperahu kuna, baik berasal dari masa prasejarah (Sebelum Masehi) maupun masa klasik. Temuan-temuan tersebut menunjukkan pula keanekaragaman teknik konstruksi dan bahan asalnya. Demikian pula halnya di Indonesia, telah ditemukan beberapa perahu kuna seperti di Situs Paya Pasir, Medan (Manguin, 1988), dan di Indramayu. Untuk melakukan interpretasi secara geografis maupun kronologis terhadap temuan- temuan tersebut, perlu dipahami terlebih dulu bagian-bagian struktur perahu yang relevan untuk diamati.

$\mathrm{Di}$ atas telah dikemukakan bahwa berdasarkan bentuk, bahan asal, dan konstruksinya, secara umum perahu dapat dikelompokkan ke dalam dua tipe perahu lesung (dug-out canoe) dan perahu papan (planked boat). Perahu lesung (Gb.1) berukuran relatif kecil dengan bentuk ramping panjang, bahan asalnya dari balok kayu utuh yang dilubangi di bagian tengahnya, dan konstruksi lambungnya polos tanpa sambungan. ${ }^{4}$ Sedangkan perahu papan (Gb.2) berukuran relatif lebih besar bila dibandingkan dengan perahu lesung, bahan asalnya berupa papan kayu yang mungkin diperoleh dari beberapa pohon yang berbeda, dan konstruksi lambungnya secara keseluruhan berupa sambungan papan-papan yang kadang-kadang dilengkapi dengan lunas.

Salah satu komponen perahu yang juga dapat digunakan sebagai dasar klasifikasi adalah tipe layar dan tiangnya. Terdapat perbedaan secara geografis dan temporal dalam bentuk-bentuk layar dan konstruksi tiang penopangnya. ${ }^{4}$

\section{B.1. Perahu Lesung}

Patokan umum untuk klasifikasi perahu lesung adalah berdasarkan ada atau tidaknya cadik (Outriggers). Di Eropa, cadik tidak dikenal, tetapi dibeberapa bagian belahan dunia dapat dijumpai perahu bercadik, seperti misalnya di kawasan Pasific, Asia Tenggara, dan Madagaskar (Johnstone 1980:50).

Tipe perahu bercadik juga dapat dikelompokkan ke dalam dua 
jenis yaitu perahu bercadik tunggal dan ganda. Jenis perahu bercadik tunggal merupakan jenis perahu lesung yang dominan didapatkan di wilayah Pulau-pulau Pasifik seperti Kepulauan Mikronesia, Polynesia, Solomon, Marquesas, dan lainnya. Di daerah ini, bahan yang sering digunakan untuk batang cadiknya ialah kayu. Jenis perahu bercadik ganda terutama didapatkan di wilayah perairan Asia Tenggara, seperti di Indonesia, Philiphina, dan Malaysia. Untuk membuat batang cadiknya, sering dipakai bahan dari bambu. Sementara itu, di daratan Asia Timur dan Tenggara, Taiwan, serta Jepang, perahu lesungnya tidak bercadik (Shibata 1989:5).

Terdapat pula perbedaan dalam hal konstruksi pemasangan cadik antara wilayah perairan Asia Tenggara dan Pasifik. Di Asia Tenggara, perahu lesung merupakan sarana transportasi di laut yang tenang dan perairan sekitar pantai. Oleh karena itu, batang cadiknya relatif panjang, dan dipasang pada struktur rangka yang mantap. Sedangkan di Pasifik kondisi lautnya seringkali ganas dan berombak besar. Dengan demikian, maka batang cadiknya lebih pendek dan besar yang dipasang pada struktur rangka yang fieksibel. 5

Perahu bercadik hanya efisien bila digunakan di sekitar perairan pantai atau perairan antar pulau. Cadik akan menjadi tidak efisien lagi dan bahkan cenderung menjadi beban untuk pelayaran laut lepas dengan ombak yang sangat besar dan angin kencang yang sering berubah arah, karena struktur perahu bercadik kurang fleksibel untuk melakukan manuver-manuver yang pendek. ${ }^{6}$

Sampai saat ini di Indonesia belum ditemukan situs yang mengandung temuan perahu lesung, sehingga perkiraan tentang bentuk perahu lesung di Indonesia pada masa lalu hanya didapatkan dari pengamatan terhadap jenis-jenis perahu lesung tradisional yang masih ada saat ini. Pada umumnya, perahu lesung tradisional Indonesia tak menyimpang dari tradisi pembuatan perahu lesung, yaitu dibuat dari satu balok kayu utuh yang dilubangi. Tetapi, penggunaan papan sisi tambahan mayoritas hanya ditemukan di daerah Irian Jaya, dan pemasangannya dengan teknik ikatan.

Perbedaan tipe perahu lesung tradisional di Indonesia antara lain dapat diamati dari bentuk penopang batang cadik dan cara pemasangan batang cadiknya. Adrian Horridge (1986:41) mencatat adanya delapan tipe cadik yaitu tipe polos (direct), jepit (stick), Madura haluan (Madura fore), Bugis-Makasar, Jawa-Bali, Madagaskar, Madura buritan (Madura aff), dan Maluku (Gb.3). Tampak di sini bahwa ada 
korelasi antara tipe cadik dengan distribusi geografis.

\section{B.2. Perahu Papan}

Seperti telah dikemukaan di atas bahwa perahu papan (plankedboat) merupakan evolusi dari perahu lesunsung. Evolusi tahap pertama dari perahu lesung menghasilkan perahu papan yang dianyam sesecara sederhana, seperti perahu-perahu di Polynesia, dan perahu suku Ainu di Jepang (Johnstone 1980:45).

Perkembangan yang tertua dari teknik pembuatan perahu papan adalah teknik yang dinamakan shell-firt. ${ }^{7}$ Pembuatan perahu dengan teknik ini dimulai dengan pemasangan papan- papan lambang terlebih dulu. Setelah "kulit luar" yang terdiri dari sambungan papan-papan terbentuk, maka langkah selanjutnya adalah pemasangan gadinggading (frames) untuk memperkuat struktur papan-papan itu. Penyambungan papan tersebut dapat dilakukan baik dengan cara anyaman / "jahitan", maupun dengan menggunakan pasak kayu (Gb.4).

Teknik penggabungan papan-papan lambung dengan cara "dijahit" (sewing) adalah teknik yang sangat tua. Pada sisi- sisi papan yang bersebarangan diberi lubang-lubang yang sejajar untuk tempat anyaman tali "benang". Bahan yang digunakan biasanya adalah serat rotan atau serat kayu yang lainnya. Teknik ini berkembang sampai sekarang di Kepulauan Pasifik. Di Luzon, Philiphina, sumber Spanyol dari tahun 1613 menyebutkan tentang penggunaan teknik ini, dan yang berkembang pula sampai sekarang (Scott 1981:4).

Penggunaan paku kayu maupun besi baru muncul sejalan dengan berkembangnya teknik pembuatan perahu yang lebih muda. Paku kayu atau besi diperlukan untuk memasang papan- papan lambung pada kerangka gading-gading dan lunas yang telah dibuat terlebih dulu.

Data visual tertua di Indonesia tentang perahu yang mungkin merupakan perahu papan didapatkan dari relief Candi Borobudur. Perahu tersebut memiliki cadik dengan batang cadik ganda. Terdapat dua tiang layar segitiga (tripod masts) dengan layar yang berbentuk segi empat miring (tilted rectangular sain). Bilah kemudinya terletak di sisi lambang (lateral rudders). Hal menarik yang terdapat pada perahu Borobudur adalah penggunaaan layar baksi segi empat yang digantung pada tiang cucur (bowsprit) (Horridge 1981:1). Layar semacam itu biasa terdapat pada kapal-kapal Eropa dari jaman Romawi sampai abad pertengahan. 
Pada masa yang lebih muda, sekitar abad ke-15-16, menurut sumber-sumber Spanyol dan Portugis di Indonesia terdapat satu tipe perahu papan yang disebut kora-kora. Deskripsi detail tentang struktur perahu ini berdasarkan sumber lukisan kuna dan sumber tertulis Eropa dilakukan oleh Horridge (1981: 5) sebagai berikut:

The hull was long and narrow, built of planks that were carved from solid hardwood, fixed edge by dowels upon a keel to from a shell. Projecting lugs were left carved in situ on the planks at intervals of a few feet. These lugs were lashed with rotan to thwarts and to flexible ribs to hold the planks together.

Satu hal penting yang dapat diamati pada struktur perahu korakora seperti tersebut di atas adalah teknik sambungan antar papan dengan menggunakan pasak, yang digabungkan dengan teknik ikatan papan terhadap gading-gading yang dipasang setelah struktur lambung perahu terbentuk (teknik shell-first). Teknik yang hampir mirip juga dapat diamati pada perahu kuna yang ditemukan di Butuan, Philiphina.

Teknik penyambungan antar papan dengan menggunakan pasak kayu juga masih dilakukan dalam pembuatan perahu tradisional masa kini di indonesia. Tetapi, teknik tersebut telah digabungkan dengan teknik yang lebih modern yang merupakan pengaruh Eropa yaitu penggunaan paku besi atau kayu, dan struktur gading-gading yang lebih mantap. Contoh perahu tradisional yang dibuat dengan menggunakan gabungan teknik itu adalah perahu dari Makasar.

Perahu tradisional Makasar mempunyai bentuk lambung khas yang dinamakan tipe pajala. Cirinya adalah dasar lambungnya yang rata dengan lunas yang menonjol, papannya dipasang di lubang yang dibuat pada linggi haluan dan buritan sehingga membentuk sudut haluan dan buritan yang tajam, dan penyambungan sisi-sisi papan dengan menggunakan pasak kayu (Horridge, 1981: 11-12).

\section{B.3. Layar}

Salah satu bagian perahu yang juga cukup penting adalah layar, yang meliputi bentuk layar dan teknik pemasangan. Secara umum, terdapat dua bentuk layar yang biasa digunakan pada perahu yaitu layar segi empat (rectangular sain) dan layar segi tiga (triangular sail). ${ }^{8}$ Kedua jenis layar tersebut membutuhkan konstruksi pemasangan yang berbeda dan pengaruh daya dorong lambung yang berbeda (Horridge, 


\section{1: 26-27)}

Distribusi tipe layar tersebut berkaitan pula dengan distribusi geografis. Tipe protolateen terdapat di Pulau- pulau Pasific seperti Kepulauan Fiji, Tonga, Cook, Marquesas, selandia Baru, dan Mikronesia (Pulau Gilbert dan Caroline). Tipe ini dipakai juga untuk perahu jukung dan janggolan di Madura. Ujung segitiga layar tipe protolateen dipasang secara tetap pada haluan perahu, dan layar dipasang pada tiang penopang (mast) yang kadang-kadang berkakitiga.

Konstruksi pemasangan layar protolateen semacam itu tidak memungkinkan layar dapat berotasi secara bebas dengan bersumbu pada tiang penopang. Horidge (1981: 26-27) mengkelompokkan dua jenis cara pemasangan layar tradisional dari masyarakat-masyarakat ras Austro-Malay yaitu layar yang dipasang secara tetap, dan layar yang dapat diputar pada satu sumbu tiang (Gb. 5). Selanjutnya Horridge mengatakan bahwa perbedaan itu merupakan ciri dari dua cabang rumpun Austro-Malay yang berbeda. Dari dua jenis tradisi pemasangan layar tersebut, tradisi protolateen adalah tradisi yang tertua (Horridge, 1981: 29).

Contoh dari tipe pemasangan layar yang kedua adalah pemasangan layar pada perahu lesung dari Makasar. Layarnya berbentuk segi empat, dan dengan menggunakan empat tali kendali layar tersebut dapat diatur sudut kemiringannya dan diputar di sekeliling tiang penopang layar (Horridge, 1981: 11).

\section{Bentuk dan Konstruksi Perahu Menurut Sumber Sejarah Tertulis}

Di antara bermacam sumber tertulis, sumber-sumber yang berasal dari Eropa seperti laporan misionaris Spanyol, Portugis, dan Belanda, serta catatan pedagang dan catatan Kekaisaran Cina, adalah sumber tertulis yang sering menceritakan tentang bentuk-bentuk perahu yang digunakan oleh pedagang. naskah tertua yang menceritakan ten-tang kapal yang datang dari wilayah Asia Tenggara adalah sumber-sumber Cina dari abad ke-3-8 M. Istilah K'un-lun Po digunakan oleh orang Cina untuk menamai kapal-kapal yang datang dari Asia Tenggara. ${ }^{9}$

Dari berbagai sumber Cina, Manguin (1980: 275-276) membuat deskripsi tentang bentuk K'un-lun Po yang merupakan kapal berukuran besar, dapat memuat $500-1000$ orang, tidak menggunakan bahan yang terbuat dari besi, mempunyai struktur papan yang berlapis, 
menggunakan beberapa layar, tidak bercadik, dan kemungkinan memiliki bilah kemudi berbentuk segi empat (quarterrudders). bentuk K'un-Iun Po itu diperkirakan adalah bentuk struktur kapal yang umum didapatkan pada masa itu di Asia Tenggara. Berita Cina selanjutnya juga mengatakan bahwa kapal-kapal yang tidak bercadik itu singgah di pelabuhan-pelabuhan di Cina selatan dalam kurun waktu abad 8 - $14 \mathrm{M}$ (Horridge, 1981: 1).

Di pihak lain, sumber-sumber Portugis juga menceritakan tentang adanya kapal-kapal dagang yang dinamakan junco. ${ }^{10}$ Deskripsi tentangnya antara lain disebutkan dalam laporan pendeta Nicolau Pereira S.J. (1528) dan Gaspar Corriera (abad XVI M).

Dari sumber-sumber teks Portugis dan Belanda, Manguin (1980: 268-272) mendeskripsikan ciri-ciri dasar sebuah jong pada sekitar abad 16-17 yaitu mempunyai tonase antara $400-500 \mathrm{~m}^{3}$, tidak menggunakan bahan dari besi, dan sambungan antar papannya menggunakan pasak kayu. Ciri-ciri ini serupa dengan ciri-ciri sebuah $K$ 'un-lun Po, sehingga dari sumber- sumber tertulis itu Manguin (lbid) mengemukakan tentang ciri-ciri teknik pembuatan kapal Asia Tenggara yaitu dibangun dengan teknik shell-first, sambungan papan antar sisi lurus, gading-gading dipasang dengan pasak kayu atau "ikatan", papan lambung yang berlapis, menggunakan dua bilah kemudi, dan bertiang layar banyak. ${ }^{11}$ Bentuk layarnya pada umumnya layar segi empat miring (canted square sail).

Teknik pembuatan perahu dan kapal di Asia Tenggara secara kronologis mengalami evolusi. Pada masa-masa awal Masehi, perahu dan kapal dibangun dengan teknik yang menyerupai teknik pembuatan perahu-perahu lesung dan papan sederhana. Teknik tersebut masih dapat diamati sisa-sisanya pada struktur perahu tradisional masa kini. Teknik pembuatan perahu dan kapal di Asia Tenggara mengalami perubahan yang mencolok setelah abad ke-16. Hal tersebut dipengaruhi oleh semakin banyaknya galangan kapal lokal yang membangun kapal- kapal Spanyol dan Portugis (Horridge, 1981: 5). Di samping. itu, pengenalan teknologi moderen dan mulai langkanya bahan dasar kayu juga mengakibatkan perubahan secara berangsurangsur dalam bentuk dan struktur lambung perahu (Shibata, 1989: 3). 


\section{Model Klasifikasi}

Pada bagian ini dicoba melakukan rangkuman uraian tentang deskripsi struktur perahu seperti yang telah tercantum di atas. Rangkuman tersebut pada akhirnya dapat digunakan sebagai patokan dasar untuk membuat standar klasifikasi tipe perahu, sehingga setiap deskripsi terhadap budaya materi yang berbentuk perahu dapat memanfaatkan standar kiasifikasi itu sebagai modelnya. Tetapi, tulisan ini belum mengarah kepada pembentukan tipologi perahu, karena untuk membentuk tipologi semacam itu diperlukan data-data yang lebih rinci.

Dari uaraian di atas, pertama dapat diamati bahwa ada keanekaragaman yang bersifat temporal dan geografis. Variabelvariabel struktural yang menunjukkan adanya keanekaragaman itu adalah papan lambung, gading-gading, dan layar. Variabel papan lambung dapat dirinci lagi menurut teknik konstruksinya yaitu berdasarkan teknik penyambungan antar papan. Pemilahan variabel gading-gading juga dilakukan atas dasar teknik pemasangannya pada papan lambung. Sedangkan untuk variabel layar dapat dilakukan perincian ke dalam tiga sub-variabel yaitu bentuk, teknik, dan tiang penopang. Perincian masing-masing variabel dan sub-variabel tersebut dilakukan terhadap perahu lesung dan perahu papan (lihat diagram di bawah). 


\section{DIAGRAM PERAHU}

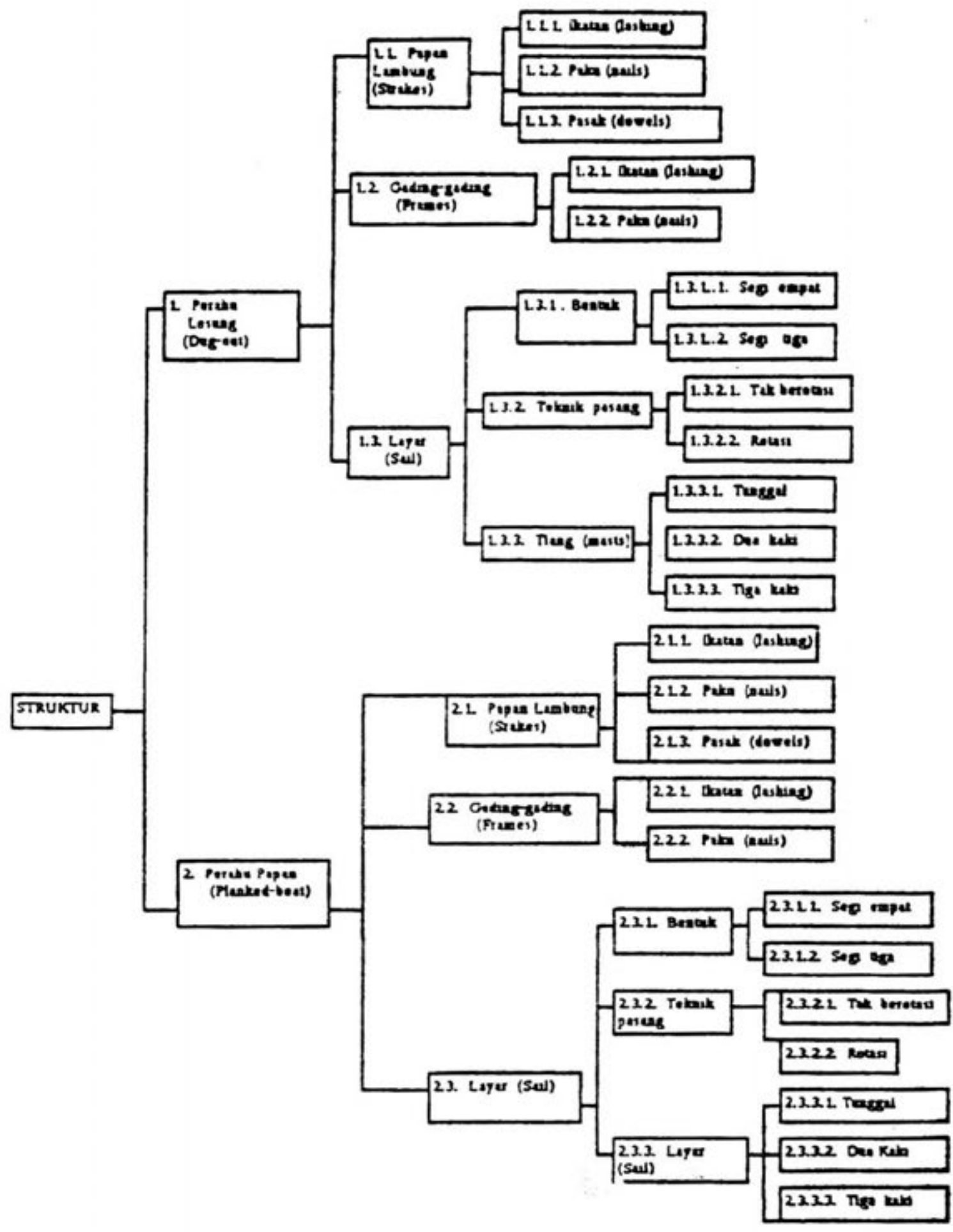




\section{E. Penutup}

Penelitian tentang arkeologi kemaritiman memang masin merupakan hal yang baru di Indonesia. Anggapan lama tentang arkeologi maritim yang hanya terbatas pada aktivitas penelitian bawah air kini sudah saatnya ditinggalkan. Penelitian di bidang arkeologi maritim harus berpijak pada latar belakang pemikiran yang berawal dari dinamika dunia kemaritiman itu sendiri. Dalam kerangka berpikir demikian itu maka penelitian arkeologi maritim tak lagi dipusatkan pada aktivitas-aktivitas bawah air belaka, tetapi yang lebih penting ialah pemahaman terhadap budaya materi yang ada dalam dunia kemaritiman.

Salah satu benda hasil buatan manusia yang berhubungan dengan dunia kemaritiman adalah perahu. Penelitian terhadap artefak perahu di Indonesi sampai saat ini belum dilakukan secara komprehensif. hal tersebut diakibatkan antara lain karena belum adanya metode analisis yang sistematis. Dengan didasarkan atas latar belakang itulah penulis mencoba mengemukakan suatu model yang dapat dimanfaatkan dalam proses analisis artefak perahu.

\section{CATATAN}

1. Kalau bergeladak biasanya disebut kapal.

2. Menurut J. Needham (1983) konstruksi lambung perahu kayu dapat dikelompokkan menjadi dua tipe yaitu clinker-built dan carvel-built. Clinker-built yaitu suatu cara penyambungan papan lambung perahu yang meletakkan satu papan di atas papan yang lainnya (overlapping). Teknik ini adalah pengembangan dari teknik "jahitan" papan pada masa yang lebih kuna. Carvel-built adalah teknik penyambungan antar sisi papan secara lurus yang diperkuat dengan penggunaan pasak kayu atau paku (Shibata, 1989: 9).

3. Kecuali terdapat sedikit papan sambungan di sisi atas lesung

4. Karena sifat bahannya yang mudah lapuk, maka jarang sekali ditemukan sisa-sisa layar di satu situs perahu kuna. Oleh karena itu, interpretasi tentang bentuk layar biasanya dilakukan dengan berpedoman pada sumber tertulis dan visual (peta kuna). Klasifikasi bentuk layar dapat dilakukan dalam pengamatan terhadap perahu- 
perahu tradisional.

5. Struktur rangka yang fleksibel didapatkan dengan cara menyambung batang-batang pendek menjadi satu penopang batang cadik yang panjang dan dipasang secara melintang pada badan perahu.

6. Menurut Manguin (1980), perahu bercadik pada relief candi Borobudur bukanlah tipe perahu lintas samudera seperti diduga sebelumnya, karena faktor keterbatasan-keterbatasan struktural perahu bercadik. Manguin (1980: 273) selanjutnya mengatakan bahwa perahu bercadik tidak lazim dijumpai pada jaman Candi Borobudur.

7. Sebenarnya ada dua teknik pembuatan perahu papan yang dikenal pada masa lalu. Teknik pembuatan yang pertama dilakukan dengan urutan sebagai berikut:

Lunas .-- Linggi haluan/buritan ---- Papan lambung --- Gading-gading Sedangkan teknik yang kedua dilakukan sebagai berikut: Lunas --- Linggi haluan/buritan --. Gading-gading --- Papan lambung

Teknik yang pertama berkembang luas di wilayah Asia dan Pasifik, sedangkan teknik yang kedua berkembang di Eropa (Scott, 1981: 3; Shibata, 1989: 9).

8. Jenis layar segi tiga disebut juga tipe protolateen.

9. Po berarti kapal, dan K'un-fun adalah istilah yang dipakai oleh orang Cina untuk menamakan wilayah Asia Tenggara (Manguin, 1980: 275).

10. Merupakan terjemahan dari jong (bhs. Melayu).

11. Biasanya berjumlah 2 - 4 tiang layar ditambah satu tiang cucur (bowsprit) 


\section{KEPUSTAKAAN}

Bray, Warwick dan David Trump, 1976, The Penguin Dictionary of Archaeology, Middlesex: Penguin Book Ltd.

Clarke, David L., 1978, Analytical Archaeology, New York: Columbia University Press.

Hole, Frank dan Robert F. Heizer, 1973, Prehistoric Archaeology: A Brief Introduction. New York: Holt, Rinehart and Wilson.

Horridge, Adrian, 1981, The Perahu: Tradisional Sailing Boat of Indonesia, Malaysia: Oxford University Press.

........ 1986, Sailing Craft of Indonesia, Singapore: Oxford University Press.

Johnstone, Paul, 1980, The Sea-Carft of Prehistory, London: Routledge and Kegan Paul Ltd.

Manguin, Pierre-Yves, 1980, The Southeast Asian Ship: An Historical Approach, dalam Journal of Southeast Asian Studies, Vol. XI, No 2., Singapore: Singapore University Press.

--a---, 1988, Report on a Brief Survey of the Paya Site Medan, LHPA Puslit Arkenas (tidak diterbitkan).

Scott, William H., 1981, Boat Building and Seamanship in Classic Philippine Society, Anthropological Paper No. 9. Manila: National Museum of Philippines.

Shibata, Keishi, 1989, Outline and Background of Fishing Boats in Southeast Asia, dalam Efren Ed. C. Flores (ed.), Comparative Studies on Indigenous Fishing Boats and Gears around the Northwestern Coasts of Pasific. Nagasaki: Working Group of Fishing Boats in Southeasts Asia, Nagasaki University.

W.J.S. Poerwadarminta, 1982, Kamus Bahasa Indonesia, Jakarta: PN. Balai Pustaka. 


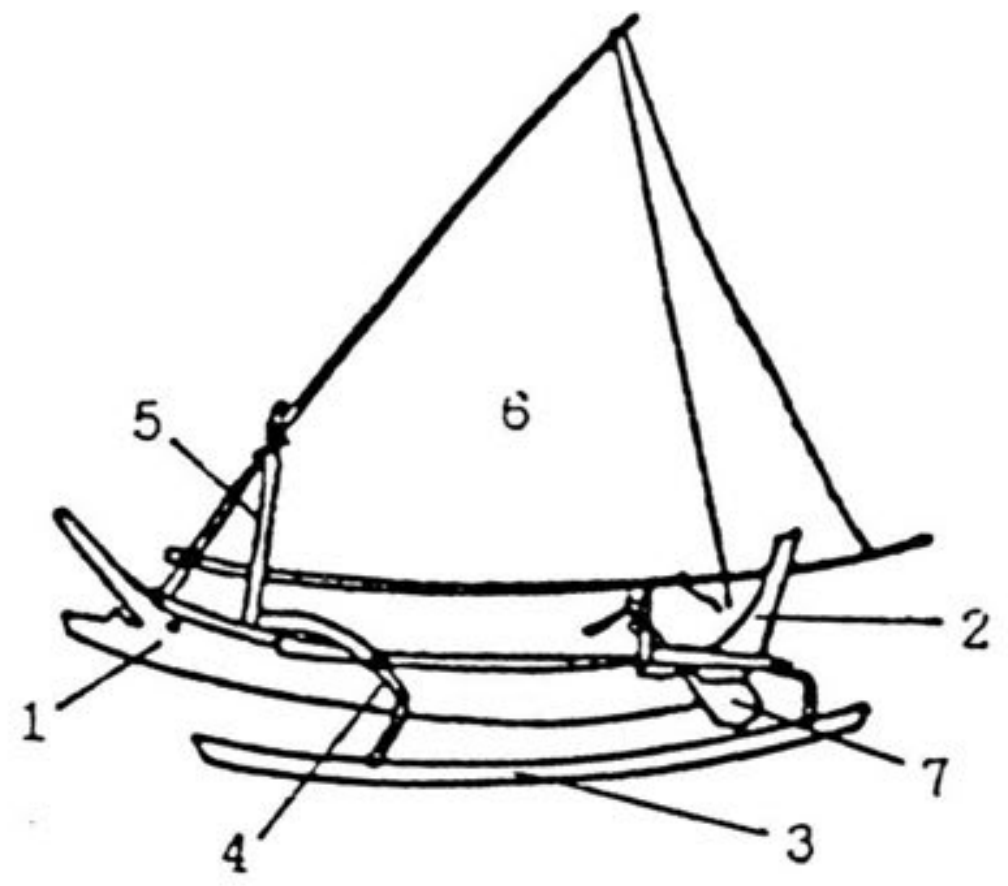

Gb. 1. Komponen-komponen struktur perahu

$$
\begin{aligned}
& \text { Ket : 1. Haluan } \\
& \text { 2. Buritan } \\
& \text { 3. Batang Cadik } \\
& \text { 4. Penopang batang cadik } \\
& \text { 5. Tiang layar } \\
& \text { 6. Layar } \\
& \text { 7. Bilah kemudi }
\end{aligned}
$$




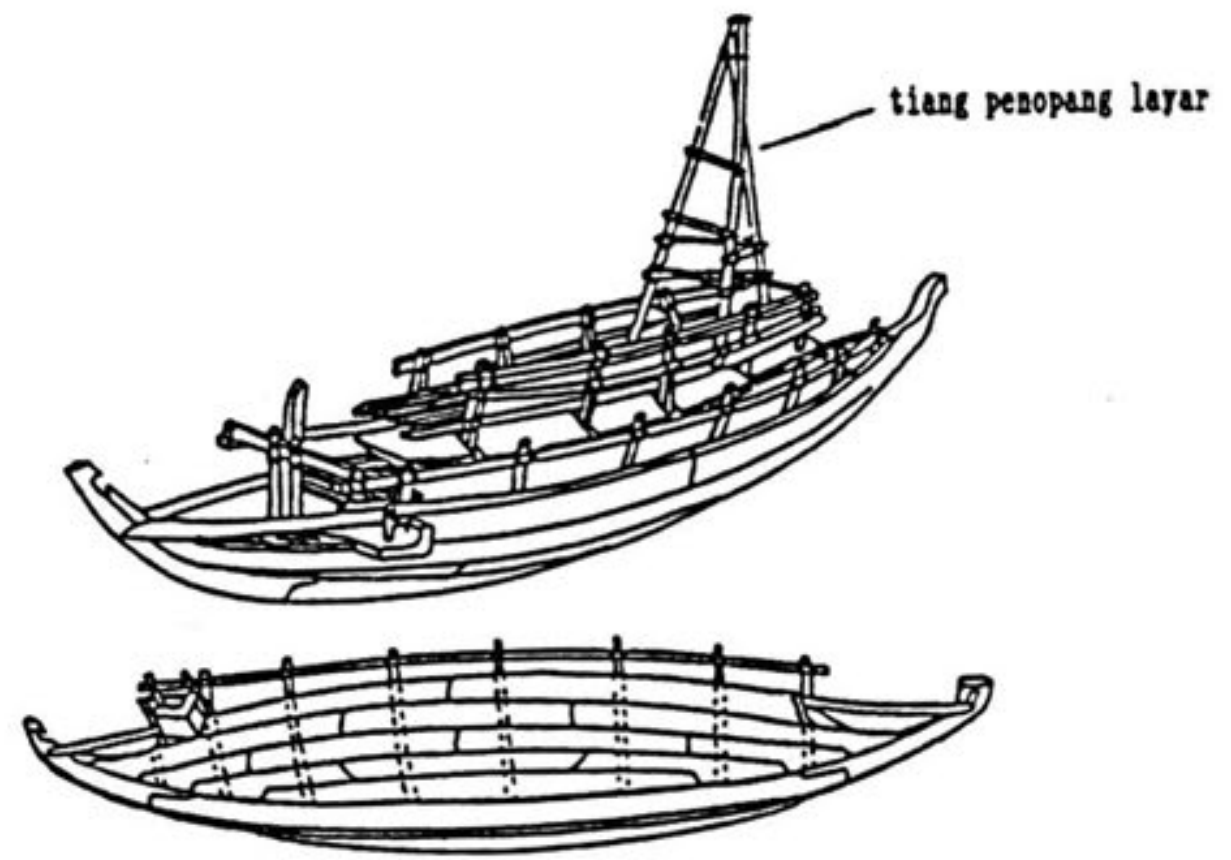

Gb. 2. Kora-kora, salah satu jenis perahu papan. Model koleks1 Tropenmuseum, Amsterdam.

(Sumber : Horridge, 1986: 53)
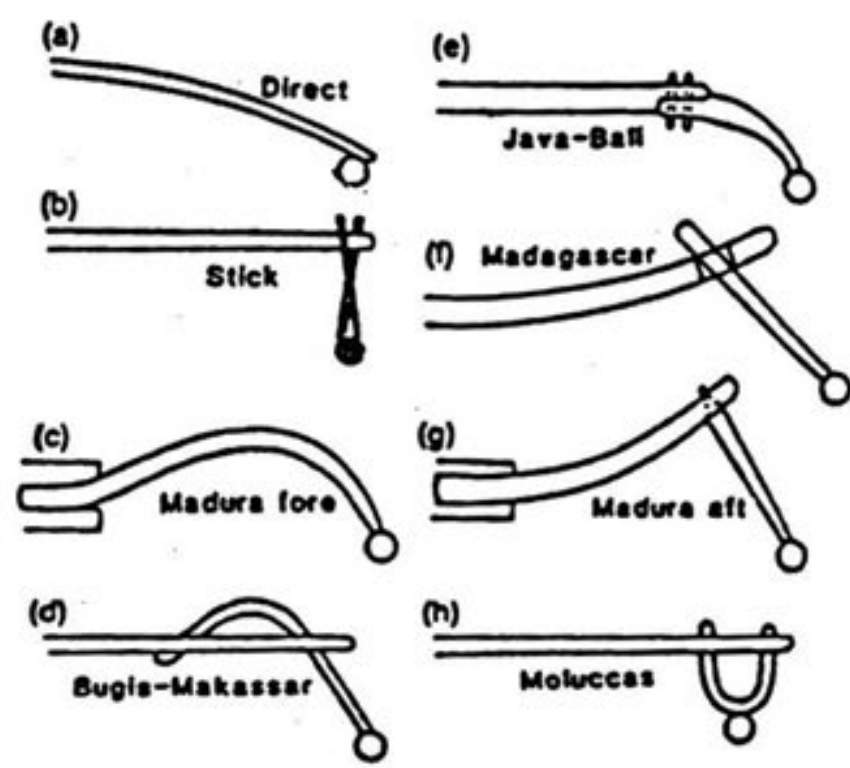

Gb. 3. Tipe pemasangan cadik

(Sumber : Horridge, 1986: 41)

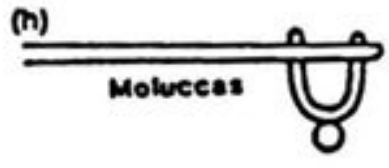



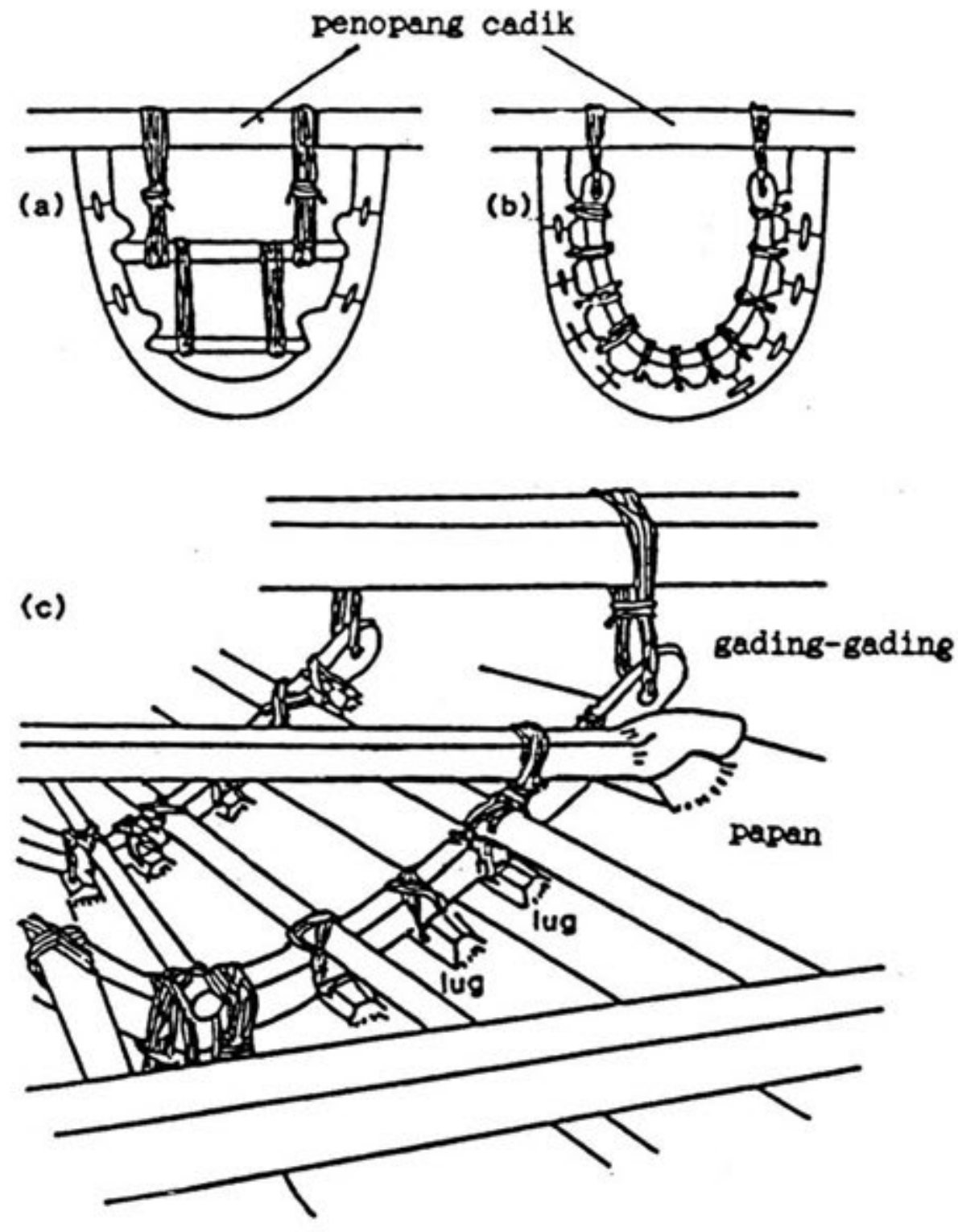

Gb. 4. Teknik shell-first dan sambungan papan dengan pasak, serta pemasangan gading-gading dengan ikatan pada lugs.

(Sumber : Horridge, 1986: 8). 

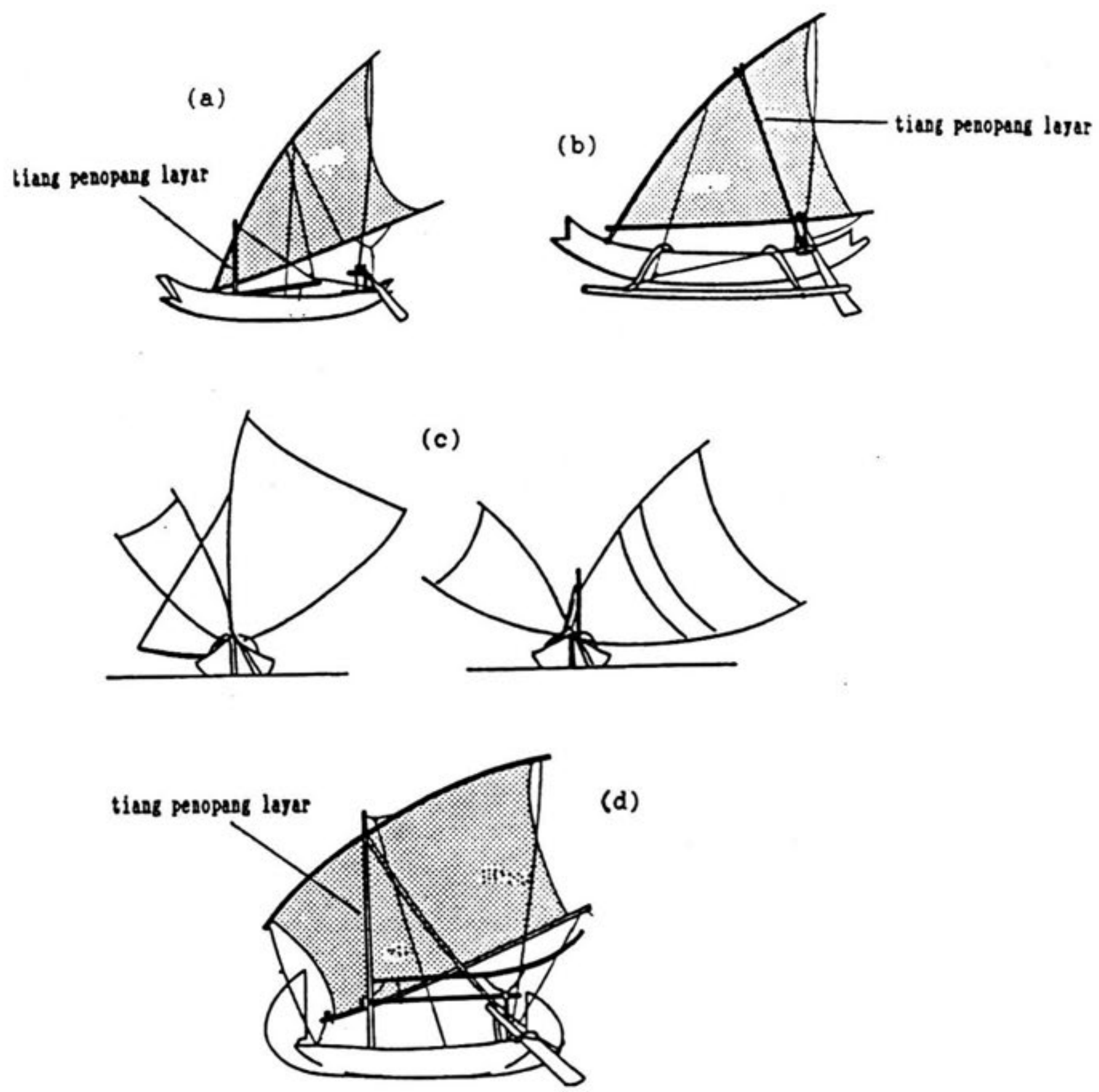

(d)

Gb. 5. Tipe-tipe layar

(a) Perahu Ifs-alis Madura, dengan layar tipe protolateen, tak dapat berotasi.

(b) Perahu jukung Madura, dengan layar tipe protolateen, tak dapat berotasi.

(c) Teknik pengendalian layar tipe protolateen.

(d) Perahu mayang Makasar, dengan layar tipe segi empat, dapat berotosi.

(Sumber : Horridge, 1981: 27-28). 